\title{
Основні результати аналізу подій на АЕС України, пов'язаних із захисною оболонкою
}

- Шугайло Олексій Петрович, канд. техн. наук Державне підприємство «Державний науково-технічний центр з ядерної та радіаційної безпеки», м. Київ, Україна ORCID: https://orcid.org/0000-0003-0997-7830

- Лігоцький Олексій Ігорович

Державне підприємство «Державний науково-технічний центр з ядерної та радіаційної безпеки», м. Київ, Україна ORCID: https://orcid.org/0000-0001-7487-2811

- Серафин Роман Ігорович Державне підприємство «Державний науково-технічний центр з ядерної та радіаційної безпеки», м. Київ, Україна ORCID: https://orcid.org/0000-0003-3917-9426

- Печериця Олександр Володимирович, канд. техн. наук Державне підприємство «Державний науково-технічний центр з ядерної та радіаційної безпеки», м. Київ, Україна ORCID: https://orcid.org/0000-0001-8711-0242

\section{- Панченко Анатолій Васильович}

Державне підприємство «Державний науково-технічний центр з ядерної та радіаційної безпеки», м. Київ, Україна ORCID: https://orcid.org/0000-0001-5376-2760

У цій статті наведені основні результати аналізу експлуатаційних подій на АЕС України та світу, пов'язаних з захисною оболонкою та системами, які забезпечують їі працездатність.

Основною метою цього аналізу було здобуття загальних та конкретних уроків, які дозволять запобігти повторенню подій у майбутньому. Обсяги аналізу охоплюють структурні елементи споруди захисної оболонки та інші системи, необхідні для забезпечення ії функціонування. Під час проведення аналізу розглянуті експлуатаційні події розділено на категорії (ті, що впливають або можуть вплинути на виконання захисною оболонкою своїх локалізуючих функцій, і ті, що не впливають). Встановлено, що до категорії подій, що впливають на виконання захисною оболонкою проєктних функцій, належать випадки відмови арматурних канатів системи переднапруження захисної оболонки і ці випадки розглянуто детально, починаючи з 1980 року з урахуванням історії та причин зміни проєктних значень зусиль натягу арматурних канатів.

Ключові слова: арматурний канат, відмова, захисна оболонка, подія, система переднапруження.

○ Шугайло О-й П., Лігоцький О. І., Серафин Р. І., Печериця О. В., Панченко А. В., 2021

\section{Вступ}

Для оцінки міжнародного досвіду експлуатації атомних електростанцій (АЕС) щодо експлуатаційних подій, пов'язаних із захисною оболонкою
(30) та системами, які забезпечують її працездатність, у цій статті наведено огляд тематичного дослідження з аналізу подій на АЕC світу, пов'язаних із 30 [1], виконаного Об'єднаним дослідницьким центром Європейської мережі зворотного зв'язку від досвіду експлуатації AEC (дослідження JRC). 
Також, наведені результати аналізу експлуатаційних подій (порушень та відхилень) у роботі АЕС України, пов'язаних із 30 та системами, які забезпечують їі працездатність. За підсумками аналізу виконано зіставлення результатів національного та міжнародного досвіду, зроблено відповідні висновки.

Нижче наведені основні результати аналізу подій на АEC України та світу, пов'язаних із 30 та системами, які забезпечують її працездатність.

\section{Результати аналізу подій на АЕС світу,} пов'язаних із 30, на основі дослідження JRC

У дослідженні [1] наведено результати огляду подій, які відбулись на АEC світу та були пов'язані з 30 (герметичним об'ємом (ГО)) та системами, які забезпечують її працездатність. Основною метою цього дослідження $\epsilon$ набуття досвіду від загальних та конкретних уроків, які дозволять запобігти повторенню подібних подій у майбутньому.

Обсяги дослідження [1] охоплюють структурні елементи споруди 30 (фундамент, стіни, облицювання, покрівлю тощо) та інші системи, необхідні для забезпечення їі функціонування (спринклерні системи, прилади для моніторингу 30, контроль водню тощо). У дослідженні [1] аналізуються експлуатаційні події, які відбулись за період з 01.01.2010 по 31.12.2019.

Основним джерелом даних для аналізу обрано звіти з міжнародної системи звітності з досвіду експлуатації (IRS) Міжнародного агентства 3 атомної енергії (МАГАТЕ), яка обслуговується спільно з Агентством з ядерної енергетики (NEA) при Організації економічного співробітництва та розвитку (OECD), а також звіти про події (LER) регулюючого органу Сполучених штатів Америки (США) - Комісії ядерного регулювання (US NRC).

За результатами детального аналізу подій для подальшого розгляду з баз даних було відібрано 391 подію.

Для відібраних подій було проведено статистичний аналіз за: станом АЕС під час події; типом 30; системами та елементами, які зазнали впливу; типом небезпеки та функціями безпеки; безпосередньою та корінною причинами; коригувальними заходами тощо.

Статистичний аналіз подій показав, що:

1) найбільша кількість подій (30 \%) відбулась у системах опалення, вентиляції та кондиціювання, а також у системах контролю та управління;

2) активні та пасивні механічні компоненти зазнавали найбільшого впливу (36 \% та $39 \%$ відповідно), водночас на компоненти контрольновимірювальних приладів припадає 18 \%;

3) основною безпосередньою причиною подій $\epsilon$ механічна відмова (32 \%);

4) найбільш поширеними корінними причинами $є:$ недоліки в технічному обслуговуванні, тестуванні або нагляді (24 \%); помилки персоналу (22\%); недоліки конструкції (18\%);

5) основними коригувальними заходами $€$ заміна або ремонт обладнання (31\%). На всі інші коригувальні заходи припадає від 9 \% до $14 \%$, винятком $€$ внесення змін у програму управління старінням - лише 0,3\%.

Крім того, за результатами дослідження JRC було зазначено, що кількість подій для киплячих реакторів (BWR) у два рази перевищує кількість подій для реакторів із водою під тиском (PWR). Така значна різниця у кількості подій пояснюється технічними особливостями AEC, а саме можливістю доступу до ГО під час експлуатації. Так, до ГО AEC з реакторами типу BWR $\epsilon$ доступ персоналу та підрядних організацій під час роботи на потужності, водночас, на AEC з реакторами типу PWR доступ до ГО зазвичай обмежується періодами зупинки реактора для виконання планово-попереджувального ремонту (ППР).

За результатами проведеного детального розгляду подій та систематизації отриманих результатів були розроблені такі рекомендації за 12 напрямами:

1) недоліки технічного обслуговування: ефективність програми технічного обслуговування повинна періодично перевірятися та вдосконалюватися. Також, вивчення історії обслуговування обладнання та всебічний аналіз кваліфікації (надійності) персоналу дає корисні інструменти для виявлення слабких сторін у практиці та процедурах обслуговування;

2) проблеми проєктування: для забезпечення виконання системами та елементами основних функцій безпеки необхідно застосовувати надійні конструкції з дотриманням перевірених інженерних практик під час проєктування АЕС. Також, профілактичні заходи з усунення або пом'якшення деградації матеріалів під час експлуатації мають бути розглянуті на етапах проєктування та будівництва (наприклад, нанесення гідроізолюючого матеріалу на зовнішню поверхню 30 має попередити виникнення тріщин у бетоні, спричинених впливом вологи);

3) недоліки документації: процедури та інструкції мають бути чіткими, технічно точними, забезпечувати належне керівництво та містити достатню кількість інформації, щоб користувачі могли зрозуміти та ефективно виконувати свої дії. Роботам, які $\epsilon$ небезпечними для персоналу або складними у виконанні, має передувати попередня підготовка (навчання) та/або відпрацювання процедури для ознайомлення 3 нею користувачів та перевірки коректності елементів управління і відповідних дій на випадок непередбачених ситуацій (аварійних тощо);

4) вдосконалення програми інспекційних перевірок: для забезпечення безпеки 
AEC, зворотного зв'язку та безперервного вдосконалення потрібно періодично проводити оцінку ефективності програми інспекційних перевірок. Програми перевірок мають бути оцінені щодо необхідності доповнення методами завчасного виявлення місць та елементів, де може потенційно виникнути дефект, що надалі, може призвести до відмови системи або елементу;

5) досвід експлуатації: відсутність або недоліки обміну інформацією, як внутрішньою, так і зовнішньою, щодо досвіду експлуатації $\epsilon$ одним із основних факторів, що сприяють виникненню подій. Своєчасний аналіз та поширення інформації про попередні подібні події дозволяє уникати повторення подій. 3 урахуванням зазначеного, важливо поширювати інформацію про досвід експлуатації, зокрема про відповідні коригувальні заходи на основі уроків, отриманих з попередніх подій, та готувати і виконувати навчальні програми для персоналу AEC та підрядних організацій;

6) система управління: керівники на всіх рівнях, враховуючи їх обов'язки, повинні забезпечити, щоб процес їх управління містив дії, направлені на заохочення звітування про проблеми, пов'язані 3 безпекою, розвиток допитливості та прагнення до засвоєння знань, та виправлення дій чи умов, які мають негативний вплив на безпеку;

7) навчання: необхідно проводити навчання 3 метою забезпечення обізнаності персоналу щодо актуальності та важливості їх діяльності та того, як їх діяльність сприяє забезпеченню безпеки;

8) нагляд:

за підрядними організаціями: під час експлуатації, технічного обслуговування або ремонту оператор повинен однаково ставитись до персоналу AEC та персоналу підрядних організацій, щоб забезпечити однаковий рівень зв'язку, інформації, підготовки та знань для виконання завдань;

за персоналом підрядних організацій: перед та під час виконання заходів на АEC (з технічного обслуговування і ремонту, нагляду і контролю тощо) оператор має поставити в рівні умови персонал AEC та персонал підрядних організацій, щоб забезпечити однаковий рівень обміну інформацією, інформованості, підготовки та знань для виконання завдань.

9) комунікація: має бути налагоджений зв'язок між різними групами персоналу (з технічного обслуговування і ремонту, експлуатації, монтажу тощо), які беруть спільну участь у виконанні конкретних робіт. Крім того, інструктаж перед виконанням зазначених робіт має проводитись із залученням усіх відповідальних робітників, зокрема персоналу підрядних організацій;

10) культура безпеки: обговорення результатів виконання конкретних робіт $\epsilon$ ефективним джерелом здобуття уроків та підвищення культури безпеки;
11) практика виконання робіт: участь персоналу у вивченні ефективності діяльності, за яку він несе відповідальність або в якій бере участь, може допомогти йому зрозуміти необхідність вдосконалення і повинна привести його до визначення заходів щодо покращення;

12) інші питання: звіти баз даних IRS та LER містять інформацію про події, важливі для безпеки, а також важливі уроки, які можуть сприяти уникненню повторення подій на інших АEC.

Результати аналізу експлуатаційних подій на АЕС України, пов'язаних із 30

Джерелами вихідних даних для виконання аналізу подій на АЕС України, пов'язаних із 30, були звіти з розслідування порушень та відхилень у роботі АЕС України, які відбулися за період з 2010 р. по 2020 р., та виникли через дефекти 30 та обладнання, яке забезпечує їі функціонування. Відбір порушень проводився за допомогою інформаційної системи «Порушення у роботі AEC» (база даних Державної інспекції ядерного регулювання (Держатомрегулювання)) та web-версії бази даних «CAESAR-і» (база даних експлуатуючої організації). Відбір порушень виконувався в два етапи.

На першому етапі було виконано початковий відбір порушень за допомогою використання кодів систем та обладнання, встановлених у словнику кодів НП 306.2.100-2004 [2], а також застосовано пошук за контекстним словом. Так, було проведено відбір подій, під час яких відбулась відмова елементів 30, або елементів, які забезпечують її працездатність, чи був вплив на обладнання систем, важливих для безпеки:

корпус, металоконструкції (код 3.AB);

система допалювання водню (код 3.BS);

система контролю щільності облицювання бака-приямка аварійного запасу розчину бору (код 3.BZ);

система контролю цілісності технологічних каналів (код 3.FG);

система захисту від перевищення тиску в реакторному просторі (код 3.GF);

система аварійного газовидалення (з I контуру, герметичних приміщень) (код 3.GK);

система герметичних огороджень (захисна оболонка, облицювання і стіни герметичних приміщень, проходки, шлюзи, люки, двері, клапани перепускні, діафрагми, «вибивні» панелі, залізобетонні захисні конструкції тощо) (код 3.НА);

система локалізуючої арматури (код 3.НB);

спринклерна система (код 3.НС);

система контролю концентрації й аварійного видалення водню (код 3.НЕ);

система очищення середовища герметичних приміщень (код 3.HF);

будівля реакторного відділення (код 3.LA); 
будівля допоміжних систем реакторного відділення (код 3.LB);

приміщення блочного, резервного щита управління (код 3.LG);

приміщення панелей автоматики (код 3.LH);

елементи будівель і споруд (код 4.10);

інше (код 4.10.00);

покрівля, перекриття (код 4.10.10);

перегородка (код 4.10.20);

стіна (код 4.10.30);

двері (код 4.10.40);

30 та їі елементи (облицювання і стіни герметичних приміщень, проходки, шлюзи, люки, двері, клапани перепускні, діафрагми, «вибивні» панелі, залізобетонні захисні конструкції тощо) (код 4.10.50);

піддон (код 4.10.60);

гідроізоляція (код 4.10.70).

Пошук за контекстним словом у назві порушення, аномальної події, причини виникнення, обладнання, яке відмовило, проведено для таких слів: «гермооболочка», «водород», «проходка», «помещение», «здание», «корпус», «крыша», «канат», «армоканат», «СПЗО», «оболочка», «стена» тощо.

За результатами початкового відбору, із 164 порушень, які відбулись за період з 2010 р. по 2020 р., для подальшого аналізу було відібрано лише 2 порушення, що $є$ недостатнім для ґрунтовного аналізу.

Враховуючи таку малу кількість порушень за вказаний період (10 років), було вирішено також розглянути експлуатаційні події (порушення та відхилення), які відбулись у більш ранній період. Для цього обрано проміжок часу з 1990 р. по 2010 р. Після цього для подальшого аналізу було відібрано 18 подій.

Аналіз розглянутих подій за обраний проміжок часу (з 1990 р. по 2020 р.) дозволив умовно розділити події на дві категорії:

Категорія 1. Порушення/відхилення, які впливають або можуть вплинути на виконання 30 своїх локалізуючих функцій;

Категорія 2. Порушення/відхилення, які не впливають на виконання 30 своїх локалізуючих функцій.
Із всього проаналізованого обсягу подій зроблено висновок, що до категорії 1 належать випадки розриву арматурних канатів (АК), які потенційно можуть призвести до втрати 30 своїх проєктних функцій (у разі множинної відмови АК).

Відомості Типового технологічного регламенту [3] свідчать про те, що експлуатація 30 можлива до наступного ППР у разі відсутності одного АК у циліндричній i/або одного АК у купольній частині 30. У разі відмови/відсутності більш ніж одного AK у циліндричній i/або у купольній частинах 30, реакторна установка (РУ) має бути переведена у стан «холодного зупину» до усунення недоліку. Перерозподіл зусиль натягу між АК, що залишились в експлуатації після обриву одного/двох АК і більше, гіпотетично може призвести до множинних відмов AK i, як наслідок, до втрати 30 проєктних локалізючих функцій. 3 урахуванням зазначених відомостей подальший акцент зроблено саме на аналізі випадків щодо відмов АК на енергоблоках АEC України і пошук цих випадків розширено із урахуванням подій, які не класифіковані як порушення (тобто розглянуті події відмови АК незалежно від її класифікації згідно з вимогами НП 306.2.100-2004 [2]).

Аналіз відібраних подій, виконано за такими напрямами:

кількість відмов за роками експлуатації енергоблоків AEC;

причини відмов.

Кількість відмов за роками експлуатації енергоблоків наведено у Таблиці 1.

Результати кількості відмов свідчать про те, що найбільшу їх кількість зафіксовано на ЮжноУкраїнській АЕС у період з 1990 р. по 2000 р. (9 подій) та на Хмельницькій АЕС з 2010 р. по 2020 р. (5 подій).

Для оцінки цієї ситуації проаналізовано дані щодо конструктивних особливостей системи переднапруження захисної 30 (СПЗО) енергоблоків AEC України та умов експлуатації AK, починаючи 3 1990 року.

Система СПЗО є одним із ключових елементів 30, до складу якої входять АК, які завдяки попередньому напруженню і обтисненню 30 забезпечують для оболонки виконання локалізуючої функції утримання радіоактивних речовин у середині 30 під час проєктної аварії і за всіх видів навантажень.

Таблиця 1 - Кількість відмов АК за роками експлуатації

\begin{tabular}{|c|c|c|c|c|}
\hline Роки $\longrightarrow A E C$ & $\begin{array}{c}\text { Южно-Українська } \\
\text { АЕС }\end{array}$ & Хмельницька АЕС & Рівненська АEC & Запорізька AEC \\
\hline 1990-2000 роки & 9 & 2 & - & - \\
\hline 2000-2010 роки & - & - & 1 & 1 \\
\hline 2010-2020 роки & - & 5 & - & - \\
\hline
\end{tabular}


Кожен АК складається з 456 високоміцних дротів діаметром 5 мм. У циліндричній частині встановлено 96 АК, а в купольній - 36 АК. По товщині стінки циліндра 30 АК розташовуються в три шари. У куполі 30 АК розташовуються у взаємно перпендикулярних напрямках у два шари за товщиною купола.

Попереднє напруження залізобетонних огороджуючих конструкцій 30 забезпечується сукупністю АК зі стабілізованого високоміцного дроту $з$ гелікоїдально-петлевою траєкторією в циліндрі і ортогонально-петлевою в куполі.

Вихідні проєкти захисної оболонки і СПЗО енергоблоків АЕС з РУ ВВЕР-1000 розроблені за часів СРСР інститутами «Атомэнергопроект» та «Оргэнергострой» (м. Москва, СРСР) у 1970-1981 роках минулого сторіччя. Експлуатацію першої 30 проєкту В-302 розпочато у 1982 році на енергоблоці № 1 Южно-Української АЕС, наступну 30 проєкту В-338 введено в експлуатацію в 1985 році і паралельно з цими енергоблоками на інших АЕС уводились в експлуатацію 30 проєкту В-320, який суттєво відрізняється від енергоблоків В-302 та В-338 геометричними розмірами 30 та конструкцією СПЗО.

СПЗО містить:

каналоутворювачі, забетоновані в залізобетонних огороджуючих конструкціях для розміщення в них АK;

АК з анкерними пристроями;

захисні ковпаки для захисту анкерних пристроїв від атмосферних впливів.

У початковий період експлуатації енергоблоків АЕС України (ВВЕР-1000) гранично-допустимі зусилля натягу AK (за яких проводилися інтегральні випробування системи ГО на міцність і герметичність) визначалися такими вимогами вихідного проєкту 30, внесеним в технічне обґрунтування безпеки енергоблока:

«Расчетное усилие преднапряжения каната арматурного 10 тыс. кН (1000 тс), минимальное контролируемое усилие натяжения каната арматурного в процессе эксплуатации - 8,5 тыс. кH (850 TC)».

Протягом експлуатації на всіх енергоблоках AEC України реєструвалися випадки обриву таких АК:

нових, змонтованих у поточний ППР і натягнутих до зусилля 1000 тс;

змонтованих раніше, але таких, що зазнали неодноразового підтягнення до 1000 тс;

крім того, за результатами контролю в ППР практично у всіх АК для всіх енергоблоків фіксувалися зусилля натягу нижчі, ніж мінімально-допустимі проєктні - 850 тс.

Причину обривів і зниження зусиль в АК було встановлено як появу пластичної деформації/ витяжки дроту (тобто існуючі АК фактично не витримували проєктні зусилля натягу).
Як наслідок, у 1995 р. окремими технічними рішеннями для кожного майданчика AEC були встановлені і погоджені Держатомрегулюванням знижені граничні значення натягу АК, які склали:

а) для енергоблоків з РУ В-302 (В-338):

«1... среднее допустимое усилие в арматурных канатах ....:

цилиндрической части - 722.8 тс нетто;

купольной части - $\quad 696.7$ тс нетто ...».

«2. Верхнее предельное усилие в арматурных канатах ... не должны превышать 875 тс (нетто). Нижний предел - 550 тс (нетто). ...»;

б) для енергоблоків з РУ В-320:

«1. ... принять минимально-допустимое усилие в арматурных канатах перед очередными котрольно-профилактическими работами (КПР) с учетом потерь за время эксплуатации между КПР в целом по оболочке:

для цилиндрической части, тс - 784;

для купольной части, тс - 762.».

«2. Верхнее предельное усилие в арматурных канатах, на тяжных анкерах канатов при подтяжках во время проведения КПР не должно превышать 875 тс (нетто). ...».

Зниження зусиль, встановлених у проєкті, було зумовлено певними технічними факторами, про які зазначено вище, і ці значення були встановлені на підставі аналітичних обґрунтувань безпеки і надійності локалізуючих систем безпеки - систем ГО із застосуванням емпіричних формул опору матеріалів і будівельної механіки. Тобто оцінка поведінки захисної оболонки у разі максимальної проєктної аварії за умови знижених зусиль в АК потребувала поглибленого аналізу порушень, що трапились за весь час експлуатації 30, і аналізу поведінки 30 із застосуванням сучасних методів розрахунку та програмних засобів.

Питання зниження зусиль в АК та здатність 30 виконувати свої функції стало ще більш актуальним після того, як у період 1998 - 2015 рр. було проведено грунтовні дослідження сейсмічної небезпеки майданчиків АEC України із застосуванням сучасних методів i засобів досліджень та з урахуванням сучасних рекомендацій МАГАТЕ. За результатами цих досліджень [4] - [7] рівні сейсмічності майданчиків AEC порівняно із прийнятним у вихідному проєкті суттєво збільшилися (кількісні показники щодо ступеня збільшення рівнів сейсмічності наведені в роботі [8]).

Така ситуація зумовила нагальну необхідність виконання робіт з переоцінки сейсмостійкості елементів і конструкцій AEC i, зокрема, визначення сейсмостійкості захисної оболонки під час сполучення навантажень $\mathrm{HE}+$ ПА+МP3 (нормальна експлуатація + проєктна аварія + максимальний розрахунковий землетрус) відповідно до вимог НП 306.2.208-2016 [9]. 
Роботи 3 оцінки сейсмостійкості $30 \quad 3$ урахуванням визначення мінімально-допустимих зусиль в АК та стійкості 30 до сполучення навантажень $\mathrm{HE}+П \mathrm{~A}+П 3$ та $\mathrm{HE}+П \mathrm{~A}+\mathrm{MP3}$ виконувались експлуатуючою організацією (EO) в межах робіт з продовження строку експлуатації енергоблоків і прийнятність цих розрахунків оцінювалась під час виконання відповідних державних експертиз ядерної та радіаційної безпеки, про що, зокрема, зазначено в роботі [10].

За результатами досліджень ЕО (зокрема [11] [17]), встановлені за аналітичними формулами значення мінімально допустимих зусиль натягу AK (див. вище), були підтверджені з урахуванням нової оцінки рівня сейсмічності майданчиків AEC України із застосуванням сучасних методів аналізу та розрахункових кодів. Збіжність результатів аналітичних розрахункових обгрунтувань того часу із сучасними обґрунтуваннями із застосуванням розрахункових кодів зумовлено консервативністю підходів, закладених в основу аналітичних методів опору матеріалів та будівельної механіки. І, як свідчить досвід робіт з обґрунтування переходу енергоблоків до довгострокової есплуатації [8], це зумовлено суттєвими запасами міцності, закладеними у вихідний проєкт елементів і конструкцій АЕС.

Аналізуючи результати виконаних досліджень щодо обґрунтування мінімально-допустимих зусиль натягу та статистики відмов АК можна зазначити, що на Южно-Українській АЕС (див. Таблицю 1) збільшення кількості подій з відмови АК у період з 1990 по 2000 роки пов'язано із тим, що початковий проєктний натяг канатів, який повинен був складати 1000 тс, призводивдоперевантаження AK із наступним розривом окремих дротів та Bсього AK і надалі зусилля натягу АК було знижено до значень, указаних В окремих технічних рішеннях для кожного енергоблока АЕС окремо, які були погоджені Держатомрегулюванням. Дві події на Хмельницькій АЕС у період 1990 - 2000 років також можуть бути пояснені зазначеними чинниками. Водночас, 5 подій на Хмельницькій AEC із відмовою АК у період з 2010 по 2020 роки проаналізовані більш ґрунтовно через частоту їх проявів за розглянутий період. Під час аналізу цих подій детально розглянуто звіти [18] - [19] про розслідування порушень.

За результатами аналізу для енергоблока № 1 Хмельницької АЕС встановлено, що у 2013 та 2020 роках стався розрив одного й того канату № 64ц. Найбільш імовірною причиною в цьому разі вважається дефектність каналоутворювача (допущена через неспіввісність у місцях з'єднання пластикових труб) прохідного перерізу каналоутворювача АК 64Ц, що призводить до виникнення додаткових напружень у місцях перегину АК на виступах і надходження вологи в каналоутворювач.
За результатами аналізу звітів про порушення [20], [21], [22] для енергоблока № 2 Хмельницької AEC встановлено, що всі три канати (24ц, 25ц та 49ц), що відмовили, уведені в експлуатацію у 1989 році із відповідними проєктними зусиллями натягу. Потім, у період мораторію з 1990 р. по 2000 р. знаходились без натягу в режимі консервації i їх підтягування знову почалось у 2001 році i продовжувалось із відповідною періодичністю до 2013 року. Причинами відмови цих канатів за результатами досліджень встановлені розрив дротів, експлуатаційний знос, корозійне пошкодження дротів із наступним розривом, тобто ніяких нових супутніх чинників не виявлено. Відмова канатів, які відпрацювали фактично 25 років, пояснюється втомою від багаторазового підтягування та недостатньою захищеністю канату від впливу навколишнього середовища і деградації дротів.

Подальшим кроком розгляду став аналіз причин, що призвели до відмов АК за весь період експлуатації. На основі аналізу відомостей про події були визначені причини відмов АК:

відсутність цілісності антикорозійного захисту; нерівномірний розподіл розтягуючих зусиль по довжині АК (релаксація АК з його підтяжкою в ППР); розрив дротів АK;

недоліки технології виробництва АК (відсутність мастила між дротами);

недоліки процедури оцінки технічного стану АК; порушення геометрії каналоутворювачів (відхилення від вимог прохідного перерізу);

завищені вимоги до зусиль натягу АК.

Із усіх проаналізованих причин відмови АК найбільш поширеними $\epsilon$ нерівномірний розподіл зусиль натягу по довжині АК та недоліки технології виробництва (якість) АК.

Нерівномірний розподіл зусиль натягу по довжині АК зумовлено конструктивними особливостями AK і каналоутворювача (натяг AK за один кінець і концентрація зусиль на ділянці підтягування із наступною релаксацією по довжині через зусилля тертя між каналоутворювачем і AK).

Загальна схема розподілу зусиль в АК під час натягу наведена на Рисунку 1 [23].

Під час натягу або підтягнення АК зусилля, що прикладається до АК домкратом на тяжному анкері, дорівнює сумі зусиль в АК і сили тертя, зумовленої взаємодією АК і каналоутворювача, тобто $\mathrm{N}_{\text {анк }}=\mathrm{N}+\mathrm{F}$; відповідно, «чисте» зусилля натягу АK поблизу анкера складає $\mathrm{N}=\mathrm{N}_{\text {анк }}-\mathrm{F}$.

Аналіз особливостей взаємодії АК СПЗО і конструкції 30 дає підстави для таких висновків:

1) працездатність 30 (рівень переднапруження конструкції) визначається «чистим» зусиллям натягу АK;

2) для визначення рівня переднапруження конструкції 30 у різних ії точках необхідно 


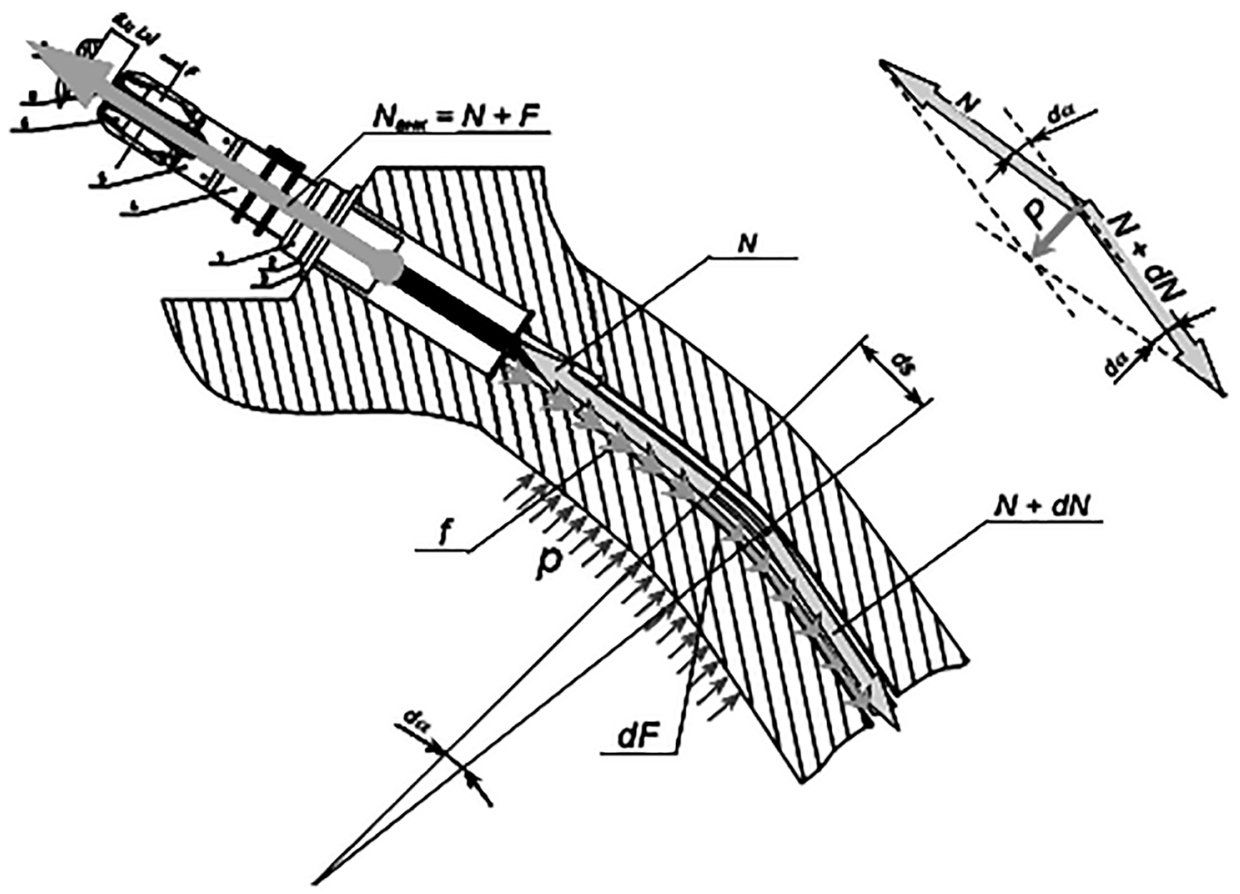

Рисунок 1 - Загальна схема розподілу зусиль в АК під час натягу

враховувати втрати зусиль в АК через тертя між АК і каналоутворювачем (використовувати коректні значення коефіцієнта тертя і кута закручування траєкторії АК на ділянці від анкера до точки конструкції 30, що розглядається).

Наявність даних про величини зусиль в АК під час натягу, їх розподіл по довжині канату в процесі експлуатації, а також поточний моніторинг фактичних зусиль в АК у режимі реального часу дозволяють знизити ймовірність розриву і відмови АК завдяки постійному відстеженню фактичних умов експлуатації канату.

3 метою моніторингу зусиль в АК у режимі реального часу на енергоблоках AEC України впроваджується система дистанційного контролю зусиль (СДКЗ) (захід № 16202 Комплексної (зведеної) програми підвищення рівня безпеки енергоблоків атомних електростанцій [24] (далі - КзППРБ)), також оснащення енергоблоків ВП АЕС з РУ ВВЕР-1000 СДКЗ передбачається п. 1 «Плана-графика внедрения мероприятий по обеспечению безопасной эксплуатации 30 энергоблоков АЭС с ЯУ ВВЭР-1000» [25].

Концептуальний підхід до вирішення питання впровадження та введення в експлуатацію СДКЗ в АК СПЗО на енергоблоках АЕС 3 РУ ВВЕР-1000 визначений та погоджений Держатомрегулюванням у галузевих концептуальних та технічних рішеннях [26]-[28], що відповідає вимогам пунктів 3.1, 3.17, 3.22 НП 306.2.106-2005 [29], які стосуються розроблення концептуального рішення про модифікацію та галузевого рішення впровадження «пілотної» модифікації на інших Яу.
Відповідно до нормативних вимог і погоджених Держатомрегулюванням галузевих та технічних рішень [26]-[28] на АЕС України реалізується захід № 16202 «Оснащення енергоблоків ВП АЕС системами дистанційного контролю зусиль в АК СПЗО» КзППРБ [24] щодо впровадження СДКЗ на всіх енергоблоках АЕС України з РУ ВВЕР-1000. Станом на вересень 2021 р. СДКЗ впроваджено майже на всіх енергоблоках; крім енергоблока № 2 Хмельницької AEC, енергоблока № 4 Рівненської АЕС та енергоблока № 5 Запорізької АЕС (монтаж СДКЗ завершено, але дослідну експлуатацію не розпочато).

Під час впровадження «пілотної» модифікації СДКЗ в АК СПЗО на енергоблоках АЕС України був врахований позитивний досвід експлуатації «пілотної» модифікації СДКЗ на енергоблоці № 1 Южно-Української АЕС (Технічне рішення [30]).

Впровадження СДКЗ в АК СПЗО на енергоблоках AEC з РУ ВBEP-1000 дає можливість виконання безперервного контролю зусиль в $100 \%$ АК СПЗО за всіх режимів роботи енергоблоків AEC 3 РУ ВВEP-1000 для забезпечення необхідного рівня попереднього напруження 30 та виконання нею своїх локалізуючих функцій.

\section{Зіставлення результатів аналізу} національного та міжнародного досвіду

Під час розгляду подій, що трапились на 30 енергоблоків з РУ ВВЕР-1000 АЕС України, до найбільш значимих, які можуть призвести до невиконання 30 своїх проєктних функцій, віднесені події, які пов'язані із відмовою (обривом) АК. Зіставлення подій на АЕС України із подіями 
на закордонних AEC за тематичним дослідженням $\mathrm{JRC}$ свідчить про те, що однозначну аналогію між подіями, що виникли, та їх порівняння провести неможливо через відсутність достатньої статистики аналогічних подій на АЕС України.
Аналіз подій із відмовою АК на енергоблоках AEC України підтверджує загальну узгодженість встановлених причин із причинами за звітом JRC. Результати аналізу та впроваджені коригувальні заходи наведено в Таблиці 2.

Таблиця 2 - Результати аналізу та впроваджені коригувальні заходи

\begin{tabular}{|c|c|c|c|c|}
\hline $\begin{array}{c}\text { Основні причини } \\
\text { відмови АК на AEC } \\
\text { України }\end{array}$ & $\begin{array}{c}\text { Кількість } \\
\text { подій для } \\
\text { цієї причини }\end{array}$ & $\begin{array}{c}\text { Зіставлення } \\
\text { з причинами } \\
\text { відмови за звітом } \\
\text { JRC [1] }\end{array}$ & Заходи з УС & $\begin{array}{l}\text { Вивчені уроки/втілені } \\
\text { коригувальні заходи }\end{array}$ \\
\hline $\begin{array}{l}\text { Відсутність цілісності } \\
\text { антикорозійного } \\
\text { захисту }\end{array}$ & 18 & $\begin{array}{l}\text { Недоліки } \\
\text { конструкції }\end{array}$ & Не передбачені & $\begin{array}{l}\text { Для захисту від впливу } \\
\text { вологи на АК виконано } \\
\text { облаштування анкерних } \\
\text { вузлів захисними ковпаками. }\end{array}$ \\
\hline $\begin{array}{l}\text { Недоліки технології } \\
\text { виробництва канатів } \\
\text { (відсутність мастила } \\
\text { між дротами) }\end{array}$ & 3 & $\begin{array}{l}\text { Недоліки } \\
\text { конструкції }\end{array}$ & Не передбачені & $\begin{array}{l}\text { Канати випускаються за ТУ } \\
\text { У 28.7-26444970-001:2019 } \\
\text { [23] , яким передбачається } \\
\text { відповідне захисне покриття, } \\
\text { мастила між дротами та } \\
\text { порядок укладання дротів. } \\
\text { Якість канатів контролюється } \\
\text { вхідним контролем. }\end{array}$ \\
\hline $\begin{array}{l}\text { Недоліки процедури } \\
\text { оцінки технічного } \\
\text { стану канатів }\end{array}$ & 4 & $\begin{array}{l}\text { Недоліки в } \\
\text { технічному } \\
\text { обслуговуванні }\end{array}$ & Не передбачені & $\begin{array}{l}\text { Прямий метод оцінки } \\
\text { технічного стану АК в процесі } \\
\text { експлуатації відсутній. } \\
\text { Непрямим методом є аналіз } \\
\text { показань системи СДКЗ } \\
\text { у процесі експлуатації } \\
\text { ЗО. СДКЗ встановлені на } \\
\text { більшості енергоблоків } \\
\text { ВВЕР-1000. }\end{array}$ \\
\hline $\begin{array}{l}\text { Завищені вимоги } \\
\text { до зусиль натягу } \\
\text { канатів }\end{array}$ & 1 & $\begin{array}{l}\text { Недоліки } \\
\text { конструкції }\end{array}$ & Не передбачені & $\begin{array}{l}\text { Вимоги до зусиль натягу } \\
\text { канатів встановлені } \\
\text { відповідними технічними } \\
\text { рішеннями на підставі } \\
\text { розрахункових } \\
\text { обґрунтувань, погоджених } \\
\text { Держатомрегулюванням. }\end{array}$ \\
\hline $\begin{array}{l}\text { Нерівномірний } \\
\text { розподіл } \\
\text { розтягуючих зусиль } \\
\text { по довжині канату } \\
\text { (релаксація канату } \\
\text { з його підтяжкою у } \\
\text { ППР) }\end{array}$ & 18 & Механічна відмова & Не передбачені & \begin{tabular}{|l} 
Через наявність \\
тертя між канатом і \\
каналоутворювачем \\
нерівномірний розподіл \\
зусиль по довжині канату є \\
конструктивною особливістю \\
експлуатації і коригуванню \\
не підлягає. Технічний \\
стан канату оцінюється за \\
показниками СДКЗ.
\end{tabular} \\
\hline Розрив дротів & 18 & Механічна відмова & Не передбачені & $\begin{array}{l}\text { Розрив дротів } є \text { загальною } \\
\text { причиною відмови усіх } \\
\text { канатів. Працездатність } \\
\text { дротів забезпечується } \\
\text { дотриманням вимог ТУ та } \\
\text { експлуатаційних процедур } \\
\text { встановлення канатів. } \\
\end{array}$ \\
\hline
\end{tabular}


Вивчені уроки та впроваджені коригувальні заходи на енергоблоках АЕС України 3 урахуванням статистки відмов свідчать про те, що кількість подій із відмовою канатів у період з 2000 по 2010 роки $\epsilon$ незначною, а у період 3 2010 по 2020 роки відмов на Запорізькій АЕС, Рівненській АEC і Южно-Українській АEC не зафіксовано. Тобто всі впроваджені коригувальні заходи загалом призвели до покращення ситуації. Винятком $\epsilon$ енергоблоки Хмельницької $\mathrm{AEC}$, для яких зафіксовано 5 відмов за останні 10 років. Причому на енергоблоці № 1 Хмельницької АЕС дві події відбулись на одному й тому ж канаті (64ц) через недоліки каналоутворювача, допущені під час будівництва, а на енергоблоці № 2 всі події відбулись без встановленої системи СДКЗ і зумовлені стандартними для всіх розривів АК чинниками, водночас нових супутніх факторів не виявлено.

\section{Висновки за результатами проведеного} аналізу

Для аналізу експлуатаційних подій (порушень та відхилень) у роботі АЕС України, пов'язаних із 30 та системами, які забезпечують іï працездатність, обрано проміжок часу з 1990 по 2020 роки. Розглянуті події були умовно розділені за категоріями (ті, що впливають (Категорія 1) або можуть вплинути на виконання 30 своїх локалізуючих функцій, i ті, що не впливають (Категорія 2)). До Категорії 1 віднесені випадки розриву АК, які потенційно можуть призвести до втрати 30 своїх проєктних функцій (18 подій). Результати кількості відмов свідчать про те, що найбільшу їх кількість зафіксовано на ЮжноУкраїнській AEC у період з 1990 по 2000 роки (9 подій) та на Хмельницькій АЕС у період з 2010 по 2020 роки (5 подій). Встановлено, що доволі значна кількість подій на Южно-Українській АEC у період 1990 - 2000 рр. пов'язана із тим, що початковий проєктний натяг канатів складав 1000 тс і призводив до перенавантаження AK із наступним розривом окремих дротів та всього АК. Надалі проєктні зусилля натягу АK було знижено до значень, указаних в окремих технічних рішеннях для кожного енергоблока AEC, і кількість подій із розривом канатів значно зменшилась (Таблиця 1).

Причини відмови АК детально проаналізовані у Таблиці 2 і засвідчили, що загалом $\epsilon$ певна узгодженість із причинами подій, визначених у дослідженні JRS [1], а саме: недоліки конструкції, недоліки в технічному обслуговуванні, механічні відмови.

Проаналізовані коригувальні заходи (Таблиця 2), впроваджені на АЕС України в останні роки, зокрема впровадження в експлуатаційну практику СДКЗ, як засобу прямого моніторингу технічного стану АК СПЗО і, відповідно, 30 загалом, та аналіз цих заходів показав загальне покращення ситуації.

За результатами виконаного аналізу експлуатаційних подій Категорії 1, зумовлених відмовами AK, як елементу, що забезпечує виконання проєктних функцій 30 протягом 1990 - 2020 рр., та аналізу результатів дослідження JRC [1], ЕО може бути рекомендовано систематично перевіряти ефективність і працездатність систем СДКЗ як засобу прямого контролю технічного стану АК та проаналізувати результати відмов АК на енергоблоках №№ 1 і 2 Хмельницької АЕС з метою визначення дієвого засобу запобігання повторювальності випадків відмови АК у майбутньому.

\section{Список використаної літератури}

1. Operating experience with containment buildings at nuclear power plants. JRC Technical Report. European Commission. Joint Research Center, 2021.

2. НП 306.2.100-2004. Положення про порядок розслідування та обліку порушень в роботі атомних електричних станцій. Затвердж. наказом Держатомрегулювання України від 01.12.2004 № 184, зареєстр. в М-ві юстиції України від 17.12.2004 за № $1594 / 10193$.

3. РГ-Б.0.03.197-17. Типовой технологический регламент безопасной эксплуатации энергоблоков АЭС с реакторами ВВЭР-1000.

4. Хмельницкая АЭС. Энергоблок № 2. Технический отчет о результатах работ по доисследованию сейсмической опасности в III томах.

5. Ривненская АЭС. Энергоблок № 4. Технический отчет о результатах работ по доисследованию сейсмической опасности в III томах.

6. Определение пикового ускорения грунта при П3, расчет поэтажных спектров ответа и максимальных ускорений при ПЗ и МРЗ. Оценка сейсмостойкости зданий и сооружений ОП ЮУ АЭС (х/д №176). Этап 1. Анализ расчетных акселерограмм, определение пикового ускорения грунта площадки ОП ЮУ АЭС при П3. Технический отчет о результатах работы. Погоджений ДІЯРУ листом від 13.11.2018 № 15-33/4-1/7635.

7. Сводный отчет по результатам «Дополнительных исследований сейсмических и сейсмотектонических условий площадки Запорожской АЭС. Создание геодинамического полигона» 191-80-О-КО-13». Погоджений ДІяРУ листом від 29.01.15 № 18-31/4-608.

8. Шугайло Ол-й П., Гребенюк Ю.П., Зелений О.В., Рижов Д.І., Шугайло Ол-р П., Брік Д.С., Черняк Я.П. Отриманий досвід та вивчені уроки щодо діяльності 3 переходу енергоблоків АЕС України до довгострокової експлуатації. Ядерна та радіаційна безпека. 2020. № 1(85). C. 15-28. doi: 10.32918/nrs.2020.1(85).02. 
9. НП 306.2.208-2016. Вимоги до сейсмостійкого проектування та оцінки сейсмічної безпеки енергоблоків атомних станцій. Затверджено наказом Держатомрегулювання від 17.10.2016 № 175, зареєстровано в Міністерстві юстиції України 07.11.2016 за № $1449 / 29579$.

10. Ляшенко Л. А., Панченко А. В., Шугайло О-й П., Коляда М. В. Результати структурного аналізу поведінки захисноїоболонки реакторів типу ВВЕР-1000/В-320вумовах запроєктної аварії. Ядерна та радіаційна безпека. 2020. № 4(88). C. 18-31. doi: 10.32918/nrs.2020.4(88).03.

11. Выполнение расчета локализующей системы системы герметичного ограждения на прочность с учетом текущего технического состояния. Энергоблок № 2. Отчет. 02.PO.XAITQ.OT.1069-15.

12. Отчет о результатах определения минимально допустимых усилий натяжения арматурных канатов (выполнение расчетного обоснования надежности защитных оболочек на соответствие требованиям нормативной документации) защитной оболочки реакторного отделения энергоблока № 3 ОП ЗАЭС. 75.93-00.01-12-13-ПР.

13. Выполнение расчетного обоснования надежности 30 (с определением минимально допустимых усилий натяжения АК) энергоблока № 3 ОП ЮУАЭС. Отчет. О५-00.526-01.02.

14. Выполнение расчета локализующей системы системы герметичного ограждения на прочность с учетом текущего технического состояния. Энергоблок № 1. Отчет. 01.PO.XA\TQ.OT.1054-15.

15. Выполнение расчетного обоснования надежности Сго лСБ энергоблока № 4 на соответствие требованиям действующих НД (определение минимально допустимых усилий натяжения арматурных канатов СПЗО). Этап 1. Отчет ОП «Запорожская АЭС». Энергоблок № 4. 181712.218.001.РК00 ред.2.

16. Выполнение расчетного обоснования надежности СгО ЛСБ энергоблока № 4 на соответствие требованиям действующих НД (определение минимально допустимых усилий натяжения арматурных канатов СПЗО). Этап 2. Отчет ОП «Запорожская АЭС». Энергоблок № 4. 181712.218.002.РК00 ред. 1.

17. Заключение по результатам оценки технического состояния и переназначения срока эксплуатации здания реакторного отделения энергоблока № 3 ОП ЮУАЭС (основания, фундаментов, стен, перекрытий, защитной оболочки, вентиляционной трубы) (х/д № 803). 803/15-02.03-ПР. Книга 3. Проверочный расчет элементов и конструкций здания РО-3.

18. Разрыв арматурного каната № 64 цилиндрической части СПЗО. Отчет о расследовании нарушения в работе AC. 1XME-007-005-11-13.

19. Разрыв арматурного каната № 64Ц цилиндрической части СПЗО. Отчет о расследовании нарушения в работе АС. 1ХМЕ(РЦ)-О07-01-10-20.

20. Разрыв арматурного каната № 49 цилиндрической части СПЗО. Отчет о расследовании нарушения в работе AC. 2XME-O07-002-04-14.
21. Разрыв арматурного каната № 24 цилиндрической части СПЗО. Отчет о расследовании нарушения в работе AC. 2XME-007-002-06-13.

22. Разрыв арматурного каната №25 цилиндрической части СПЗО. Отчет о расследовании нарушения в работе AC. 2XME-007-004-10-13.

23. Крицкий В.Б., Шугайло А.П., Панченко А.В., Рыжов Д.И. Основные регулирующие требования к проектированию и эксплуатации защитных оболочек (30) энергоблоков АЭС с РУ ВВЕР-1000. Анализ опыта работ на АЭС Украины по обоснованию работоспособности и обеспечению надежного функционирования 30. Учебный семинар ГНТЦ ЯРБ. Киев, ГНТЦ ЯРБ, 09.10.2015 г.

24. Комплексна (зведена) програма підвищення рівня безпеки енергоблоків атомних електростанцій. Затверджена постановою Кабінету Міністрів України від 07.12.2011 № 1270.

25. План-график внедрения мероприятий по обеспечению безопасной эксплуатации 30 энергоблоков АЭС с ЯУ ВВЭР-1000.

26. О внедрении системы измерения усилий в АК СПЗО энергоблоков АЭС Украины с РУ ВВЭР-1000. Отраслевое концептуальное решение ТРМ-М.1234.03.103-06, погоджене Держатомрегулюванням України 28.07.2006.

27. О порядке внедрения систем дистанционного контроля усилий в АК СПЗО энергоблоков с РУ ВВЭР-1000. Отраслевое техническое решение ОТР-М.1234.03-150.10, погоджене Держатомрегулюванням України 12.02.2010.

28. О дальнейшем внедрении систем дистанционного контроля усилий в АК СПЗО энергоблоков с РУ ВВЭР-1000. Отраслевое техническое решение ОТР-М.1234.03-159.10, погоджене Держатомрегулюванням 30.08.2010.

29. НП 306.2.106-2005. Вимоги до проведення модифікацій ядерних установок та порядку оцінки їх безпеки. Затверджено наказом Держатомрегулювання України 10.01.2005 № 4, зареєстровано в М-ві юстиції України 24.01.2005 № 78/10358.

30. О вводе в промышленную эксплуатацию системы дистанционного контроля усилий В армоканатах (СДКУ-1000) СПЗО энергоблока № 1. Техническое решение № TP.1.0907.2057 от 20.01.2010.

\section{References}

1. JRC Technical Report. Operating experience with containment buildings at nuclear power plants. (2021). European Commission. Joint Research Center.

2. NP 306.2.100-2004. Provision on the procedure for investigation and accounting of NPP events. Approved by SNRIU Order No. 184 of 1 December 2004, registered in the Ministry of Justice under No. 1594/10193 on 17 December 2004.

3. RG-B.0.03.197-17. Standard technical specifications for safe operation of WWER-1000 NPPs. 
4. Khmelnitsky NPP. Power unit 2. Technical report on the results of additional investigation of seismic hazard in III volumes.

5. Rivne NPP. Power unit 4. Technical report on the results of additional investigation of seismic hazard in III volumes.

6. Determination of peak ground acceleration under $\mathrm{OBE}$, calculation of floor response spectra and maximum accelerations under OBE and SSE. Assessment of seismic resistance of buildings and structures of SU NPP (No. 176). Stage 1. Analysis of estimated accelerograms, determination of peak ground acceleration of SU NPP site under OBE. Technical report on work results. Agreed by SNRIU by letter No. 15-33/4-1/7635 of 13 November 2018.

7. Consolidated report on the results of "Additional studies of seismic and seismotectonic conditions of the Zaporizhzhya NPP site. Creation of a geodynamic test site 191-80-O-KO-13". Agreed by SNRIU by letter No. 18-31/4-608 of 29 January 2015.

8. Shugailo, O., Grebenyuk Yu., Zelenyi O., Ryzhov, D., Shugaylo, Ol-r., Brick, D., Cherniak, Ya. (2020). Experience Obtained and Lessons Learnt from the Transition of Ukrainian NPPs to Long-Term Operation. Nuclear and Radiation Safety. 1(85), 15-28. doi: 10.32918/nrs.2020.1(85).02.

9. NP 306.2.208-2016. Requirements for seismic design and assessment of seismic safety of NPP units. Approved by SNRIU Order No. 175 of 17 October 2016, registered in the Ministry of Justice under No. 1449/29579 (as amended) on 7 November 2016.

10. Liashenko, L., Panchenko, A., Shugailo, O-i., Koliada, M. (2020). Results of Structural Analysis of WWER-1000/320 Containment Behavior under Severe Accidents. Nuclear and Radiation Safety. 4(88), 18-31. doi: 10.32918/nrs.2020.4(88).03.

11. Report. Strength calculation of a confining system containment system, taking into account current technical condition. Power unit 2. 02.PO.XAITQ.OT.1069-15.

12. Report on the results of determining the minimum permissible tension of reinforced tendons (feasibility study of containments for compliance with the requirements of regulatory documents) of the reactor building containment for ZNPP-3. 75.93-00.01-12-13-PR.

13. Report. Feasibility study of containment reliability (with the determination of the minimum permissible tension of reinforced tendons) for SU NPP-3. OCh-00.526-01.02.

14. Report. Strength calculation of a confining system containment system, taking into account current technical condition. Power unit 1. 01.PO.XAITQ.OT.1054-15.

15. ZNPP report. Power unit 4. Feasibility study of CSS containment reliability for power unit 4 for compliance with the requirements of current RD (determination of the minimum permissible tension of reinforced tendons of the containment pre-tensioning system). Stage 1 . 181712.218.001.RK00 rev.2.

16. ZNPP report. Power unit 4. Feasibility study of CSS containment reliability for power unit 4 for compliance with the requirements of current RD (determination of the minimum permissible tension of reinforced tendons of the containment pre-tensioning system). Stage 2 . 181712.218.002.RK00 rev.1.
17. Conclusion on the results of technical condition assessment and lifetime extension for the reactor building of SU NPP-3 (basement, foundations, walls, ceilings, containment, ventilation pipe) (No. 803). 803/15-02.03-PR. Book 3. Verification calculation of components and structures of RO-3 building.

18. 1XME-007-005-11-13. Report on an incident in the operation of the nuclear power plant. Tendon № 64 failure in cylindrical part of the containment prestressing system..

19.1XME(РЦ)-O07-01-10-20. Report on an incident in the operation of the nuclear power plant. Tendon № 64 Ц failure in cylindrical part of the containment prestressing system.

20. 2XME-007-002-04-14. Report on an incident in the operation of the nuclear power plant. Tendon № 49 failure in cylindrical part of the containment prestressing system.

21. 2XME-007-002-06-13. Report on an incident in the operation of the nuclear power plant. Tendon № 24 failure in cylindrical part of the containment prestressing system.

22. 2XME-007-004-10-13. Report on an incident in the operation of the nuclear power plant. Tendon № 25 failure in cylindrical part of the containment prestressing system.

23. Krytskyi, V., Shugailo, O., Panchenko, A., Ryzhov, D. Basic regulatory requirements for the design and operation of WWER-1000 NPP containments. Analysis of the experience of activities at NPPs of Ukraine to justify operability and ensure reliable operation of the containment. SSTC NRS training workshop. Kyiv, SSTC NRS, 9 October 2015.

24. Schedule for measures to provide safe operation of the containment with WWER-1000 NPP units.

25. On implementation of the system for measuring tension in reinforced tendons of the containment pretensioning system at WWER-1000 NPPs in Ukraine: branch concept decision TPM-M. 1234.03.103-060 agreed by SNRIU on 28 July 2006.

26. On the procedure for implementing the systems for remote control of tension in reinforced tendons of the containment pre-tensioning system at WWER-1000 NPPs: branch concept decision OTP-M.1234.03-150.10, agreed by SNRIU on 12 February 2010.

27. On further implementing the systems for remote control of tension in reinforced tendons of the containment pre-tensioning system at VVER-1000 NPPs: branch concept decision OTP-M.1234.03-159.10, agreed by SNRIU on 30 August 2010.

28. NP 306.2.106-2005. Requirements for modifications of nuclear facilities and procedure for their safety assessment. Approved by SNRIU Order No. 4 of 10 January 2005, registered in the Ministry of Justice on 24 January 2005 under No. 78/10358.

29.Comprehensive (consolidated) program to increase the level of safety of nuclear power units, approved by the resolution of the Cabinet of Ministers of Ukraine of December 7, 2011 for № 1270.

30. On putting into commercial operation of the system for remote control of tension in reinforced tendons (SDKU-1000) of the containment pre-tensioning system for power unit 1: technical solution No. TR.1.0907.2057 of 20 January 2010. 


\section{The Main Results from Analysis of the Events at Ukrainian NPPs Related to Containment}

\section{Shugailo O-i, Ligotskyy O., Serafyn R., Pecherytsia O., Panchenko A.}

State Enterprise «State Scientific and Technical Center for Nuclear and Radiation safety», Kyiv, Ukraine

The main goal of the analysis of operational events at Ukrainian NPPs and around the world related to the containment was obtaining the general and specific lessons that would prevent the repetition of events in the future. The scope of the analysis covers the structural elements of the containment and other systems necessary to ensure its functioning. During the analysis, operational events are divided into categories (those that affect or may affect the performance of confining functions by the containment and those that do not affect (Category 2). Category 1 includes cases of failure of reinforcing tendons, which can potentially lead to the loss of containment design functions (18 events). These cases have been considered in detail since 1990, taking into account the history and reasons for changes in the design forces of tendons tension.
The causes of tendons failure analyzed in detail in this paper show that there is a general coincidence with events identified in the study "JRC Technical Report. Operating experience with containment buildings at nuclear power plants. European Commission. Joint Research Center, 2021", namely design lacks, maintenance deficiencies, mechanical failures.

The lessons learned and corrective measures implemented in the last 10 years at the Ukrainian NPPs, taking into account the failure statistics, show that the number of tendons failure events in the period from 2000 to 2010 is insignificant, and in the period from 2010 to 2020, failures for ZNPP, RNPP and SUNPP are not recorded. This justify that all implemented corrective measures in general have led to a significant improvement of the situation.

Keywords: tendons, failure, containment, events, overstrain system.

Отримано 02.08.2021 